\title{
STATISTICAL OPTIMISATION OF CELL GROWTH AND CAROTENOID PRODUCTION BY RHODOTORULA MUCILAGINOSA
}

\author{
Iriani R. Maldonade ${ }^{1 *}$, Delia B. Rodriguez-Amaya ${ }^{2}$, Adilma R. P. Scamparini \\ ${ }^{1}$ Embrapa Hortaliças, Brasília, DF, Brasil; ${ }^{2}$ Departamento de Ciência de Alimentos, Faculdade de Engenharia de Alimentos, \\ Universidade de Campinas, Campinas, SP, Brasil.
}

Submitted: April 07, 2010; Returned to authors for corrections: April 15, 2011; Approved: January 16, 2012.

\begin{abstract}
Sequential statistical methods were used to maximise carotenoid production by a strain of Rhodotorula mucilaginosa, isolated from the Brazilian ecosystem. Initially, a factorial $2^{5-1}$ experimental design was used, and the variables were $\mathrm{pH}$ and the levels of glucose, yeast extract, $\mathrm{MgSO}_{4} \cdot 7 \mathrm{H}_{2} \mathrm{O}$ and $\mathrm{KH}_{2} \mathrm{PO}_{4}$. The nitrogen source (yeast extract) was the most important variable in enhancing carotenoid production; $\mathrm{MgSO}_{4} .7 \mathrm{H}_{2} \mathrm{O}$ and $\mathrm{KH}_{2} \mathrm{PO}_{4}$ had a negative influence. The initial $\mathrm{pH}$ had no significant effect on carotenoid and cell productions. We further investigated the effects of glucose and yeast extract effects, using a second-order central composite design (CCD) to optimise carotenoid production, which was adequately approximated with a full quadratic equation obtained from a two-factor-2-level design. The analysis of quadratic surfaces showed that after 5 days of cultivation at $25^{\circ} \mathrm{C}$, the maximum carotenoid concentration $\left(745 \mu \mathrm{g} \mathrm{l^{-1 }}\right)$ was obtained with $15 \mathrm{~g} \mathrm{l}^{-1}$ of yeast extract and $20 \mathrm{~g} \mathrm{l}^{-1}$ of glucose. The maximum carotenoid production $(152 \mu \mathrm{g}$ $\mathrm{g}^{-1}$ ) was obtained with $5 \mathrm{~g} \mathrm{l}^{-1}$ yeast extract and $10 \mathrm{~g} \mathrm{l}^{-1}$ glucose. Carotenoid formation was more sensitive to changes in yeast extract concentration than to changes in glucose concentration. Maximum cell production was achieved with $15-17 \mathrm{~g} \mathrm{l}^{-1}$ of yeast extract and 15-20 $\mathrm{g} \mathrm{l}^{-1}$ of glucose.
\end{abstract}

Key words: fermentation, torulene, yeast, response surface design, Rhodotorula mucilaginosa

\section{INTRODUCTION}

Carotenoids have special properties that make them important to food quality and human health. As natural pigments, they impart the pleasing yellow, orange and red colours of many foods. Some of these compounds are precursors of vitamin A, the deficiency of which persists as a serious public health problem in developing countries. Both provitamin $\mathrm{A}$ and vitamin $\mathrm{A}$-inactive carotenoids can reduce the risk of the development of degenerative diseases such as cancer, cardiovascular diseases, cataract and macular degeneration $(1,9,12,15,22)$. The red carotenoid astaxanthin $(3,3$ '-dihydroxy- $\beta, \beta$-carotene-4,4'-dione) is used as feed pigment in the aquaculture industry, particularly for salmon and trout. Because of their many applications, carotenoids sources continue to be sought. Carotenoids can reach the consumers as natural constituents of foods, as additives that serve as colourants of food or as food supplements.

\footnotetext{
*Corresponding Author. Mailing address: Embrapa Hortaliças, CP 218, Brasília-DF, CEP 70359-970, Brazil.; Tel.: +55-61-33859000 Fax: +55-61-35565744.; E-mail:
} 
Carotenoid biosynthesis is characteristic of yeasts from the genus Rhodotorula. The major carotenoids produced are torulene $\quad\left(3^{\prime}, 4^{\prime}\right.$-didehydro- $\beta, \psi$-carotene $), \quad \beta$-carotene $\quad(\beta, \beta$ carotene) and torularhodin (3',4'-didehydro- $\beta, \psi$-caroten-16'-oic acid) $(3,6,16,21)$. Torulene is an interesting carotenoid for commercialisation. Because of its 13 conjugated double bonds, it has a nice reddish colour, in contrast to $\beta$-carotene (11 conjugated double bonds), which has a yellow to orange colour that depends on the concentration. Structurally, torulene fulfills the minimum requirement for a provitamin A carotenoid: an unsubstituted $\beta$-ring with an 11-carbon polyene chain. This carotenoid should be an efficient antioxidant because the antioxidant property of carotenoids is associated with the conjugated double bond system and the efficiency is higher with a greater number of double bonds. Torularhodin, the carboxylated derivative of torulene, was found in in vitro studies to be more potent than $\beta$-carotene in quenching singlet oxygen and scavenging peroxyl radicals $(18,19)$.

Carotenogenesis depends on the strains, which produce variable quantities of different carotenoids, and on the culture conditions, which affect yeast growth and metabolite production. The relative concentrations of individual pigments can be altered by modifying fermentation conditions, such as the $\mathrm{pH}$, carbon and nitrogen sources, temperature and presence and levels of salts and light. However, the biotechnological production of carotenoids is limited by high cost, but this problem can be reduced by optimising the process conditions. Production of biomass should also be considered because it can be used in animal feed as a protein source $(4,7,8,14)$.

In the present work, we optimised the culture conditions for the production of carotenoids by wild Rhodotorula mucilaginosa, which was isolated in Brazil. For this purpose, a statistical experimental design was employed rather than the one-factor-at-a-time approach. Therefore, the effects of various factors, including the interaction of factors, could be simultaneously investigated. $R$. mucilaginosa was chosen because it was previously shown (10) to produce torulene as the principal carotenoid.

\section{MATERIALS AND METHODS}

\section{Microorganism and culture conditions}

Wild yeast Rhodotorula mucilaginosa-137, which was isolated from the soil of Campinas, São Paulo, Brazil, and previously identified (11), was used throughout this study. The culture was maintained by monthly transfers to yeast malt-agar (YM) slants containing $0.3 \mathrm{~g} \mathrm{l}^{-1}$ yeast extract, $0.3 \mathrm{~g} \mathrm{l}^{-1}$ malt extract, $0.5 \mathrm{~g} \mathrm{l}^{-1}$ peptone, $10 \mathrm{~g} \mathrm{l}^{-1}$ glucose and $20 \mathrm{~g} \mathrm{l}^{-1}$ agar, and was stored at $4{ }^{\circ} \mathrm{C}$. Each starter culture was prepared by inoculating one loop of a slant culture into $200 \mathrm{ml}$ of YM medium in a $500 \mathrm{ml}$ Erlenmeyer flask and incubating at $25^{\circ} \mathrm{C}$ with shaking at $200 \mathrm{rpm}$ for $72 \mathrm{~h}$ in a rotary shaker. Fermentation was carried out in $500 \mathrm{ml}$ Erlenmeyer flasks containing $200 \mathrm{ml}$ of media prepared with different combinations of initial $\mathrm{pH}$ and levels of glucose, yeast extract, $\mathrm{MgSO}_{4} .7 \mathrm{H}_{2} \mathrm{O}$ and $\mathrm{KH}_{2} \mathrm{PO}_{4}$. Each flask was inoculated with 7.5 $\%\left(\mathrm{v} \mathrm{v}^{-1}\right)$ of the starter culture and incubated at $25{ }^{\circ} \mathrm{C}$ with shaking at $200 \mathrm{rpm}$ in a rotary shaker for 5 days in the dark. Because of the many variables investigated in this paper, the effects of light and temperature will be reported in a separate paper. Cell growth was monitored periodically by measuring the absorbance at $600 \mathrm{~nm}$ of samples withdrawn aseptically from the flasks, using a Beckman model DU-640 UV/visible spectrophotometer. The cells were harvested by centrifugation at $10,000 \mathrm{x} \mathrm{g}$ for $10 \mathrm{~min}$ at $5^{\circ} \mathrm{C}$, washed twice with distilled water and centrifuged again. The dry mass was gravimetrically determined after drying the centrifuged and washed cells at 105 ${ }^{\circ} \mathrm{C}$ to a constant weight.

\section{Analytical procedures}

The glucose concentration was measured in the supernatant according to the dinitrosalicylic acid (DNS) method (13). The amount of cell protein was determined by the Kjeldahl method using the general factor of 6.25.

The carotenoid content was determined according to 
procedures described by Maldonade et al. (10, 11) and Rodriguez-Amaya (17). Wet cells were collected by centrifugation, macerated with Hyflosupercel and acetone with a mortar and pestle, and filtered. Extraction and filtration were repeated until the residue turned colourless. The carotenoids were transferred to petroleum ether in a separatory funnel by the addition of water and were subsequently washed free of acetone. The pigment solution was dried with anhydrous sodium sulphate and concentrated in a rotary evaporator $(<40$ $\left.{ }^{\circ} \mathrm{C}\right)$. The absorbance at $481 \mathrm{~nm}$ was determined, and the total carotenoid concentration was calculated according to the formula provided by Davies (5) using the absorption coefficient of torulene $\left(\mathrm{A}^{1 \%}{ }_{1 \mathrm{~cm}}=3240\right)$, the principal

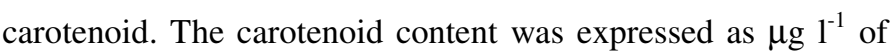
medium and $\mu \mathrm{g} \mathrm{g}^{-1}$ of dry cell. The carotenoid yield in terms of sugar consumed $\left(\mathrm{Y}_{\mathrm{P} / \mathrm{S}}\right)$ was also calculated. It was defined as $\mathrm{Y}_{\mathrm{P} / \mathrm{S}}=\left(\mathrm{P}_{\mathrm{f}}-\mathrm{P}_{\mathrm{i}}\right) /\left(\mathrm{S}_{\mathrm{i}}-\mathrm{S}_{\mathrm{f}}\right)$, where $\mathrm{S}_{\mathrm{i}}$ and $\mathrm{P}_{\mathrm{i}}$ were the substrate and total carotenoid concentration $\left(\mu \mathrm{g} \mathrm{l}^{-1}\right)$ at the beginning of fermentation, respectively, and $S_{f}$ and $P_{f}$ were the substrate and total carotenoid concentration $\left(\mu \mathrm{g} \mathrm{l}^{-1}\right)$ at the end of fermentation, respectively.

\section{Experimental design}

The experimental data were submitted to analysis of variance (ANOVA) using the Statistica for Windows software (20). A $2^{5-1}$ factorial design (2) was used to study the effect of medium components on yeast growth and carotenoid production. The experimental variables were initial $\mathrm{pH}$ and the concentrations of glucose, yeast extract, $\mathrm{MgSO}_{4} \cdot 7 \mathrm{H}_{2} \mathrm{O}$ and $\mathrm{KH}_{2} \mathrm{PO}_{4}$ (Table 1). Based on the results of this initial design, a $2^{2}$ factorial design with three replicates at the center point was employed to study the combined effect of yeast extract and glucose concentrations on carotenoid production. The yeast and glucose concentrations evaluated are presented in Table 2. The experimental data were analyzed by the response surface regression procedure using the software Statistica for Windows software version $7.0(20)$.

\section{RESULTS AND DISCUSSION}

\section{Significant culture factors}

The factorial design $2^{5-1}$ determined the independent factors that had a greater influence on carotenoid and biomass production. The results obtained after 5 days of incubation are presented in Table 1; the reproducibility of replicate flasks was very good $\left(\mathrm{R}^{2}=0.99\right)$. The biomass varied from 1.1 to $11 \mathrm{~g} \mathrm{l}^{-1}$. The greatest biomass production occurred in assay 16, which used medium ( $\mathrm{pH}$ 6) consisting of $40 \mathrm{~g} \mathrm{l}^{-1}$ glucose, $5 \mathrm{~g} \mathrm{l}^{-1}$ yeast extract, $1 \mathrm{~g} \mathrm{l}^{-1} \mathrm{MgSO}_{4} .7 \mathrm{H}_{2} \mathrm{O}$ and $8 \mathrm{~g} \mathrm{l}^{-1} \mathrm{KH}_{2} \mathrm{PO}_{4}$. Carotenoid production varied from 59 to $904 \mu \mathrm{g} \mathrm{l^{-1 }}$, maximum production was obtained in assay 8 using with medium also consisting of $40 \mathrm{~g} \mathrm{l}^{-1}$ glucose and $5 \mathrm{~g} \mathrm{l}^{-1}$ yeast extract but without salt supplementation. The yield was only $50 \mu \mathrm{g} \mathrm{g}^{-1}$ of sugar, which indicates that the amount of glucose in the medium could be reduced based on the high residual sugar concentration. In $\mu \mathrm{g}$ $\mathrm{g}^{-1}$, assays 5 and 8 gave the highest carotenoid concentration of 173 and $162 \mu \mathrm{g} \mathrm{g}^{-1}$, respectively, with concentrations ranging from 32 to $173 \mu \mathrm{g} \mathrm{g}^{-1}$. In assay 5, the medium ( $\left.\mathrm{pH} 4\right)$ consisted of $10 \mathrm{~g} \mathrm{l}^{-1}$ glucose and $5 \mathrm{~g} \mathrm{l}^{-1}$ yeast extract without salt supplementation.

The experimental results were used to estimate the main effects of variables and their interactions (data not shown). Only yeast extract had a positive effect on carotenoid production. An increase in yeast extract concentration stimulated both cell growth and carotenoid formation. The addition of $\mathrm{KH}_{2} \mathrm{PO}_{4}$ promoted a significant negative effect on the parameters evaluated, whereas magnesium sulphate had a positive effect on biomass formation but a negative effect on carotenoid production in $\mu \mathrm{g} \mathrm{g}^{-1}$. Because a carbon source is essential for microbial growth, glucose had a positive effect on yeast growth but no significant effect on carotenoid production. The initial $\mathrm{pH}$ did not significantly influence biomass production nor carotenoid formation. The interactions between variables were not significant in terms of biomass and carotenoid production in $\mu \mathrm{g} \mathrm{l}^{-1}$, except for the interaction between glucose and yeast extract. 
Table 1. $2^{5-1}$ factorial design with coded values and experimental results obtained after 5 days of fermentation for biomass production, carotenoid production and yield.

\begin{tabular}{|c|c|c|c|c|c|c|c|c|c|c|}
\hline \multirow[b]{2}{*}{$\begin{array}{c}\text { Assay } \\
\text { no. }\end{array}$} & \multicolumn{4}{|c|}{ Variables* } & \multicolumn{6}{|c|}{ Results } \\
\hline & $\overline{\mathbf{A}}$ & $\overline{\mathbf{B}}$ & $\bar{C}$ & D & $\mathbf{E}$ & $\begin{array}{c}\text { Carotenoid } \\
\text { production }\left(\mu \mathrm{g} \mathrm{l}^{-1}\right)\end{array}$ & $\begin{array}{c}\text { Carotenoid } \\
\text { production }\left(\mu \mathrm{g} \mathrm{g}^{-1}\right)\end{array}$ & $\begin{array}{c}\text { Yield } \\
\left(\mu \mathrm{g} \mathrm{g^{-1 }} \text { sugar }\right)\end{array}$ & $\begin{array}{c}\text { Biomass } \\
\left(\mathrm{g} \mathrm{l}^{-1}\right)\end{array}$ & $\begin{array}{c}\text { Residual } \\
\text { sugar }\left(\mathrm{g} \mathrm{l}^{-1}\right)\end{array}$ \\
\hline 1 & 4 & 10 & 1 & 0 & 8 & 59 & 53 & 10 & 1.1 & 4.1 \\
\hline 2 & 6 & 10 & 1 & 0 & 0 & 255 & 138 & 39 & 1.8 & 3.5 \\
\hline 3 & 6 & 40 & 1 & 0 & 0 & 160 & 76 & 18 & 2.1 & 31 \\
\hline 4 & 6 & 40 & 1 & 0 & 8 & 142 & 77 & 15 & 1.8 & 31 \\
\hline 5 & 4 & 10 & 5 & 0 & 0 & 665 & 173 & 70 & 3.8 & 0.6 \\
\hline 6 & 6 & 10 & 5 & 0 & 8 & 445 & 128 & 46 & 3.5 & 0.3 \\
\hline 7 & 4 & 40 & 5 & 0 & 8 & 678 & 139 & 44 & 4.9 & 25 \\
\hline 8 & 6 & 40 & 5 & 0 & 0 & 904 & 162 & 50 & 5.6 & 22 \\
\hline 9 & 4 & 10 & 1 & 1 & 0 & 389 & 93 & 41 & 4.2 & 0.6 \\
\hline 10 & 6 & 10 & 1 & 1 & 8 & 145 & 32 & 15 & 4.5 & 0.7 \\
\hline 11 & 4 & 40 & 1 & 1 & 8 & 243 & 56 & 16 & 4.4 & 25 \\
\hline 12 & 6 & 40 & 1 & 1 & 0 & 431 & 80 & 29 & 5.4 & 25 \\
\hline 13 & 4 & 10 & 5 & 1 & 8 & 731 & 120 & 75 & 6.1 & 0.2 \\
\hline 14 & 6 & 10 & 5 & 1 & 0 & 758 & 122 & 78 & 6.2 & 0.2 \\
\hline 15 & 4 & 40 & 5 & 1 & 0 & 397 & 47 & 17 & 8.5 & 16 \\
\hline 16 & 6 & 40 & 5 & 1 & 8 & 713 & 67 & 27 & 11 & 14 \\
\hline 17 & 5 & 25 & 3 & 0.5 & 4 & 670 & 77 & 34 & 8.7 & 5.1 \\
\hline 18 & 5 & 25 & 3 & 0.5 & 4 & 671 & 72 & 33 & 9.3 & 4.5 \\
\hline 19 & 5 & 25 & 3 & 0.5 & 4 & 620 & 68 & 30 & 9.1 & 4.5 \\
\hline
\end{tabular}

\section{Optimum medium composition}

Based on the results of the initial factorial design, the composition of the medium was optimised by examining the variable (yeast extract) that positively influenced carotenoid production and glucose, which would be essential for growth. The experimental results for the two-factor-three-level response surface analysis are shown in Table 2 . The biomass of R. mucilaginosa-137 ranged from 2.5 to $8.0 \mathrm{~g} \mathrm{l}^{-1}$ with the maximum biomass obtained with 15 to $20 \mathrm{~g} \mathrm{l}^{-1}$ glucose and 15 to $17 \mathrm{~g} \mathrm{l}^{-1}$ yeast extract. Carotenoid production $\left(\mu \mathrm{g} \mathrm{g}^{-1}\right.$ dry cell) varied from 84 to 152 ; the maximum production (127 to 152 $\mu \mathrm{g} \mathrm{g}^{-1}$ ) occurred with 7.9 to $10 \mathrm{~g} \mathrm{l}^{-1}$ glucose and 5 to $10 \mathrm{~g} \mathrm{l}^{-1}$ yeast extract. The carotenoid concentration $\left(\mu \mathrm{g}^{-1}\right)$ varied from 250 to $745 \mu \mathrm{g} \mathrm{l}^{-1}$ and reached the maximum concentration (730 to $745 \mu \mathrm{g} \mathrm{l}^{-1}$ ) with 15 to $20 \mathrm{~g} \mathrm{l}^{-1}$ glucose and 10 to $15 \mathrm{~g} \mathrm{l}^{-1}$ yeast extract. The protein content of the biomass ranged from 39 to $68 \%$. The maximum range was achieved with 10 to $15 \mathrm{~g} \mathrm{l}^{-1}$ yeast extract and 20 to $22 \mathrm{~g} \mathrm{l}^{-1}$ glucose. Compared to the control assay, which produced about $340 \mu \mathrm{g} \mathrm{l}^{-1}$ carotenoids and $6.2 \mathrm{~g}^{-1}$ biomass in the YM medium, the production of carotenoids and biomass has increased significantly.

The full quadratic models of these results were tested for adequacy by ANOVA (Table 3). The model for biomass has satisfactory values of $\mathrm{R}^{2}=0.987$ and is significant at the $5 \%$ level. The $\mathrm{F}$ value of 76.17 for biomass is greater than $F_{5,5}$ (5.05) within a rejection region with an $\alpha$-level that is $\mathrm{p}<0.05$; thus, this model can be used to predict the results in the studied region. 
Table 2. $2^{2}$ factorial design values and experimental results obtained from fermentation of $R$. mucilaginosa-137 with varying concentrations of glucose and yeast extract.

\begin{tabular}{|c|c|c|c|c|c|c|c|}
\hline \multirow[b]{2}{*}{ Assays } & \multicolumn{2}{|c|}{ Variables } & \multicolumn{5}{|c|}{ Results } \\
\hline & $\begin{array}{l}\text { Yeast extract } \\
\left(\mathrm{g} \mathrm{l}^{-1}\right)\end{array}$ & $\begin{array}{c}\text { Glucose } \\
\left(\mathrm{g} \mathrm{l}^{-1}\right)\end{array}$ & $\begin{array}{c}\text { Biomass } \\
\left(\mathrm{g} \mathrm{l}^{-1}\right)\end{array}$ & $\begin{array}{c}\text { Carotenoid } \\
\text { production }\left(\mu \mathrm{gl}^{-1}\right)\end{array}$ & $\begin{array}{c}\text { Carotenoid } \\
\text { production }\left(\mu \mathrm{g} \mathbf{g}^{-1}\right)\end{array}$ & $\begin{array}{c}\text { Residual } \\
\operatorname{sugar}\left(\mathrm{g} \mathrm{l}^{-1}\right)\end{array}$ & $\begin{array}{c}\text { Protein } \\
(\%)\end{array}$ \\
\hline 1 & 5.0 & 10 & 3.2 & 488 & 152 & 0.3 & 47 \\
\hline 2 & 15 & 10 & 6.5 & 679 & 104 & 0.5 & 55 \\
\hline 3 & 5.0 & 20 & 5.3 & 609 & 116 & 2.6 & 52 \\
\hline 4 & 15 & 20 & 8.0 & 745 & 93 & 0.8 & 68 \\
\hline 5 & 10 & 7.9 & 5.0 & 637 & 127 & 0.4 & 51 \\
\hline 6 & 10 & 22 & 7.4 & 671 & 91 & 2.2 & 56 \\
\hline 7 & 2.9 & 15 & 2.5 & 250 & 100 & 3.5 & 39 \\
\hline 8 & 17 & 15 & 8.0 & 671 & 84 & 0.7 & 55 \\
\hline 9 & 10 & 15 & 6.6 & 702 & 106 & 0.6 & 49 \\
\hline 10 & 10 & 15 & 6.5 & 728 & 111 & 0.5 & 51 \\
\hline 11 & 10 & 15 & 6.4 & 732 & 114 & 0.5 & 52 \\
\hline
\end{tabular}

At 95\% significant level $(\mathrm{p}<0.05)$

Table 3. Analysis of variance for the regression model of carotenoid production (after ignoring the insignificant effects) and biomass, obtained from the response surface experiments.

\begin{tabular}{|c|c|c|c|c|c|c|}
\hline \multirow[t]{2}{*}{ Source } & \multicolumn{3}{|c|}{$\begin{array}{c}\text { Carotenoid production } \\
\left(\mu \mathrm{g} \mathrm{l}^{-1}\right)\end{array}$} & \multicolumn{3}{|c|}{$\begin{array}{c}\text { Biomass } \\
\left(\mathrm{g} \mathrm{l}^{-1}\right)\end{array}$} \\
\hline & SS & Df & MS & SS & Df & MS \\
\hline Regression & $184,558.8$ & 3 & $61,519.6$ & 32.105 & 5 & 6.421 \\
\hline Residual & $24,645.7$ & 7 & $3,520.81$ & 0.4217 & 5 & 0.0843 \\
\hline Lack of fit & $24,115.0$ & 5 & $4,823.0$ & 0.4017 & 3 & 0.1339 \\
\hline Pure error & 530.7 & 2 & 265.3 & 0.020 & 2 & 0.010 \\
\hline Total & $209,204.5$ & 10 & & 32.527 & 10 & \\
\hline F model & & 17 & & & 76.1 & \\
\hline $\mathrm{MS}_{\mathrm{L}} / \mathrm{MS}_{\mathrm{Pe}}$ & & 18 & & & 13.3 & \\
\hline $\mathrm{R}^{2}$ & & 0. & & & 0.98 & \\
\hline
\end{tabular}

$\mathrm{SS}=$ Sum of square; $\mathrm{Df}=$ Degrees of freedom; MS = Media square;

$\mathrm{MS}_{\mathrm{L} f} / \mathrm{MS}_{\mathrm{Pe}}=$ MS Lack of fit/ MS Pure error;

$\mathrm{F}_{5,2}=19.30 ; \mathrm{F}_{3,7}=4.35 ; \mathrm{F}_{5,5}=5.05 ; \mathrm{F}_{3,2}=19.16$

The model for carotenoid production $\left(\mu \mathrm{g}^{-1}\right)$ had to be adjusted because the $\mathrm{F}$ value (8.25) obtained was greater than $\mathrm{F}_{5,5}$ (5.05), but the $\mathrm{MS}_{\mathrm{Lf}} / \mathrm{MS}_{\mathrm{Pe}}$ (27.73) was greater than $\mathrm{F}_{3,2}$ (19.16) (data not shown). By adjusting the model and ANOVA and ignoring the insignificant effects, the new regression obtained is better. The F model (17.47) is much greater than $\mathrm{F}_{3,7}(4.35)$, and $\mathrm{MS}_{\mathrm{R}} / \mathrm{MSr}=18.18$ is lower than $\mathrm{F}_{5,2}(19.30)$, which suggests that the adjusted model can better predict the results than the complete model. Using a multiple regression analysis of the experimental data in Table 3 and excluding insignificant terms, the final models are as follows:
Biomass $\left(\mu \mathrm{g} \mathrm{l}^{-1}\right)=6.50+1.72 \mathrm{X}-0.62 \mathrm{X}^{2}+0.87 \mathrm{Y}-$ $0.14 \mathrm{Y}^{2}-0.15 \mathrm{X} . \mathrm{Y}$

Total carotenoid $\left(\mu \mathrm{g} \mathrm{l}^{-1}\right)=706.47+115.30 \mathrm{X}-107.40$ $\mathrm{X}^{2}+29.38 \mathrm{Y}$

where $\mathrm{X}$ represents yeast extract $\left(\mathrm{g} \mathrm{l}^{-1}\right)$ and $\mathrm{Y}$ represents glucose $\left(\mathrm{g} \mathrm{l}^{-1}\right)$.

The regression models were employed to develop the response surface plots shown in Figure 1. Figure 1-B shows that carotenoid production $\left(\mu \mathrm{g}^{-1}\right)$ was more sensitive to changes in yeast extract concentration than to changes in glucose concentration in the region studied. The highest values 
for carotenoid production occurred with approximately 12 to $16 \mathrm{~g} \mathrm{l}^{-1}$ yeast extract. Figure 1-A shows that biomass was affected by the independent variables yeast extract and glucose. The best condition in the region studied for biomass and carotenoid production by $R$. mucilaginosa was in the range of 15 to $20 \mathrm{~g} \mathrm{l}^{-1}$ glucose and 15 to $17.07 \mathrm{~g} \mathrm{l}^{-1}$ yeast extract. Under these conditions, the yeast yielded $8.0 \mathrm{~g} \mathrm{l}^{-1}$ biomass and a maximum total carotenoid production of $745 \mu \mathrm{g} \mathrm{l} \mathrm{l}^{-1}$ after $120 \mathrm{~h}$ of fermentation, indicating approximately $33 \%$ higher biomass and $52 \%$ higher total carotenoid production than with the control (6.2 $\mathrm{g} \mathrm{l}^{-1}$ and $340 \mu \mathrm{g} \mathrm{l}^{-1}$, respectively).

A

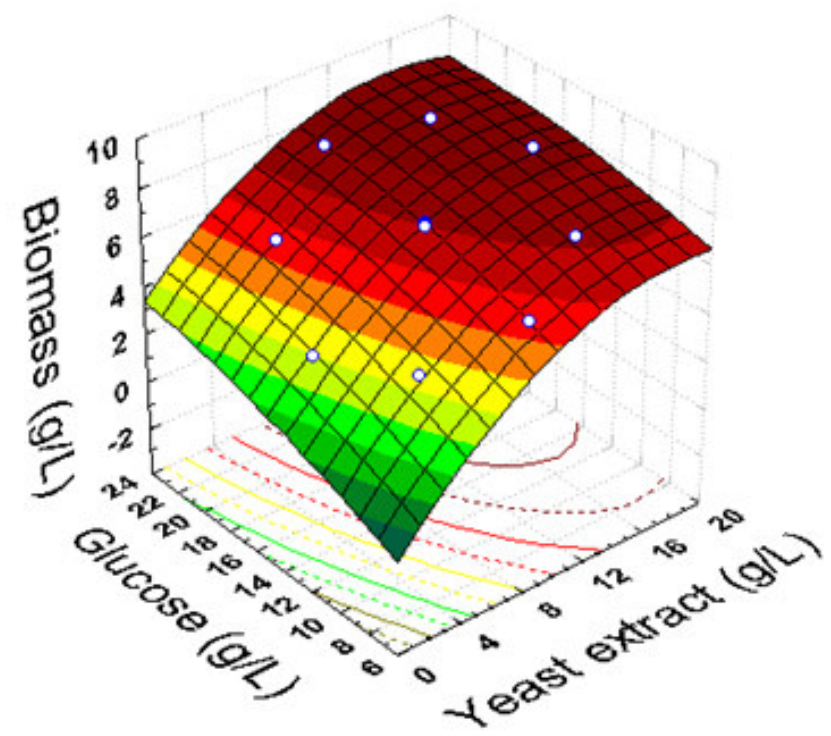

B

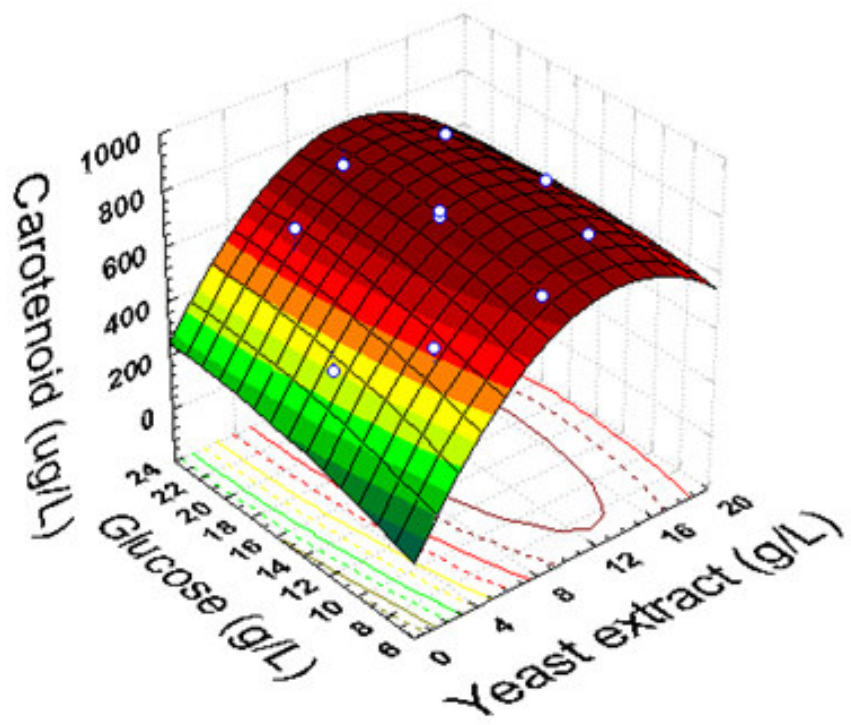

Figure 1. Response surface diagrams as a function of yeast extract and glucose concentrations: (A): biomass production $\left(\mathrm{g} \mathrm{l}^{-1}\right)$; (B): carotenoid production $\left(\mu \mathrm{g}^{-1}\right)$. 


\section{CONCLUSION}

Yeast extract is a good source of nitrogen for the production of carotenoids by $R$. mucilaginosa. Because of the increase in residual sugar in the medium and the cost and yield of the process, glucose concentrations should not be higher than $20 \mathrm{~g} \mathrm{l}^{-1}$. The optimal cell production was achieved with 15-17 $\mathrm{g} \mathrm{l}^{-1}$ yeast extract and 15-20 $\mathrm{g} \mathrm{l}^{-1}$ glucose. Maximum carotenoid concentration was obtained with $15 \mathrm{~g} \mathrm{l}^{-1}$ yeast extract and $20 \mathrm{~g} \mathrm{l}^{-1}$ glucose. Both biomass and carotenoid productions $\left(\mu \mathrm{g} \mathrm{l}^{-1}\right)$ adjusted well to the mathematical model, which means that both can be predicted by the established equations. Considering that yeast growth and carotenoid production did not have a direct correlation, two-stage batch fermentation appears to be more appropriate for the production of carotenoids by Rhodotorula mucilaginosa. In the first stage, the yeast could grow under higher concentrations of nitrogen and carbon; in the second stage, carotenoid production can be enhanced by placing the yeasts under stress with light, salts and oxygen.

\section{REFERENCES}

1. Astorg, P. (1997). Food carotenoids and cancer prevention: An overview of current research. Trends Food Sci. Technol. 8, 406-413.

2. Barros, B.; Scarminio, I.S.; Bruns, R.E. (1996). Planejamento e otimização de experimentos. Unicamp (ed.), São Paulo-Brazil, p. 133165.

3. Buzzini, P.; Martini, A.; Gaetani, M.; Turchetti, B.; Pagnoni, U.M.; Davoli, P. (2005). Optimization of carotenoid production by Rhodotorula graminis DBVPG 7021 as a function of trace element concentration by means of response surface analysis. Enz. Microb. Technol. 36, 687-692.

4. Costa, I.; Martelli, H.L; Da Silva, I.M.; Pomeroy, D. (1987). Production of $\beta$-carotene by a Rhodotorula strain. Biotech. Lett. 9, 373-375.

5. Davies, B.H. (1976). Carotenoid. In: Goodwin, T. W. (ed.), Chemistry and Biochemistry of Plant Pigments. Academic Press, New York, p. 38165.

6. Frengova, G.; Simova, E.; Pavlova, K.; Beshkova, D.M.; Grigrova, D.
(1994). Formation of carotenoids by Rhodotorula glutinis in whey ultrafiltrate. Biotechnol. Bioeng. 44, 888-894.

7. Johnson, E.A.; Lewis, M.J.; Grau, C.R. (1980). Pigmentation of egg yolks with astaxanthin from the yeast Phaffia rhodozyma. Poult. Scienc. $59,1777-1782$.

8. Johnson, E.A.; Conklin, D.E.; Lewis, M.J. (1977). The yeast Phaffia rhodozyma as a dietary pigment source for salmonoids and crustaceans. J. Fish Res. Board Canada. 34, 2417-2421.

9. Krinsky, N.I.; Johnson, E.J. (2005). Carotenoid actions and their relation to health and disease. Mol. Aspects. Med. 26, 459-516.

10. Maldonade, I.R.; Rodriguez-Amaya, D.B.; Scamparini, A.R.P. (2008). Carotenoids of yeasts isolated from the Brazilian ecosystem. Food Chem. 3, 159-164.

11. Maldonade, I.R.; Scamparini, A.R.P.; Rodriguez-Amaya, D.B. (2007). Selection and characterization of carotenoid-producing yeasts from Campinas region, Brazil. Brazilian J. Microbiol. 38, 1-6.

12. Mayne, S.T. (1996). Beta-carotene, carotenoids, and disease prevention in humans. FASEB J. 10, 690-701.

13. Miller, G.L. (1959). Use of dinitrosalicylic acid reagent for determination of reducing sugar. Anal. Chem. 31, 426-428.

14. Nelis, H.J.; Deleenheer, A.P. (1991). Microbial sources of carotenoid pigment used in foods and feeds: a review. J. Appl. Bacteriol. 70, 181191.

15. Olson, J.A. (1999). Carotenoids and human health. Arch. Latinoamer. Nutr. 49, 7-11.

16. Park, P.K.; Kim, E.Y.; Chu, K.H. (2007). Chemical disruption of yeast cells for the isolation of carotenoid pigments. Sep. and Purific. Techno.l $53,148-152$.

17. Rodriguez-Amaya, D.B. (1999). A Guide to Carotenoids Analysis. International Life Sciences, Institute Press, p. 64.

18. Sakaki, H.; Nochide, H.; Komemushi, S.; Miki, W. (2002). Effect of active oxygen species on the productivity of torularhodin by Rhodotorula glutinis N²1. J. Biosci. Bioeng. 93, 338-340.

19. Sakaki, H.; Nakanishi, T.; Tada, A.; Miki, W.; Komemushi, S. (2001). Activation of torularhodin production by Rhodotorula glutinis using weak white light irradiation. J. Biosci. Bioeng. 92, 294-297.

20. SAS (1990). SAS: User's Guide: Statistics (Version 6a). SAS Institute Inc., Cary, North Carolina, USA.

21. Simpson, K.L.; Chichester, C.O.; Phaff, H.J. (1971). Carotenoid pigments of yeast. In: Rose A.H., Harrison J.S. (eds.), The Yeasts. Academic Press, New York, vol 2, p. 493-515.

22. Tapiero, H.; Townsend, D.M.; Tew, K.D. (2004). The role of carotenoids in the prevention of human pathologies. Biomed Pharmacother. 58, 100110 . 